\title{
Shore Times, Cycles and Rhythms
}

\author{
Francesca Dal Cin* and Sérgio Barreiros Proença \\ Lisbon School of Architecture, Universidade de Lisboa, Portugal
}

Submission: December 04, 2020; Published:February 02, 2021

Corresponding author: Francesca Dal Cin, formaurbis LAB, CIAUD - Research Centre of Architecture Urbanism and Design, Lisbon School of Architecture, Universidade de Lisboa, 1349-063, Lisboa, Portugal

\section{Abstract}

Coastal cities will suffer the increasing effects of the rise in average sea level caused by climate change. The mediating space between the urban agglomeration and the water body, the shore, acts as a barrier and protection for the city's public space, the seashore street. However, the low and sandy shore, due to erosive phenomena caused by extreme events, is losing mass and exposing the coastal settlement to flooding. In predicting extreme scenarios caused by climate change, knowing the times, cycles and rhythms of the shoreline and the effects of sea level rise is necessary to decode new approaches to urban edge adaptation.

Keywords: Climate Change; Sea Level Rise; Flooding; Erosion; Shore; Coastal Settlements; Adaptation; Seashore Streets

\section{Introduction}

The issue of climate change has taken on greater importance in the international scientific debate in recent years, because it affects and influences cities and the interaction of complex systems [1-3]. Among the consequences of global warming is the rise in the average sea level, as reported by the IPCC [4]. The increasingly alarming effects require conscious management, development of models and measures to facilitate adaptation of the coastal system [5]; where the effects of rising sea levels, flooding and erosion, are most visible. The coastal space, especially the low and sandy shore, is the place that mediates several urban settlements and the water body. As the shore is the place where social relations take place, where different forms of use have developed over time. A space initially dedicated to fishing related activities - from the construction and shelter of boats to fish commerce - later appropriated for recreational and leisure activities, such as sea bathing and summer tourism.

The coastal cities interface with the sea to the urban public space, the seashore street: where buildings overlook the ocean, and the public space becomes promenade but also in a quay [6,7]. In the relationship of proximity between the urban settlement and the sea, the shore allows the reduction of wave impact in extreme flood scenarios. In fact, the approximation of the shoreline, the mobile and natural line, to the waterfront, the rigid edge of the city, caused by the rising sea level reduces the space of the shore and this generates different negative environmental, social and economic externalities.

\section{Discussion}

The sandy shore is a complex system whose transformations are gradual and progressive in their variables, due to winds, tidal cycles and now the effects of sea level rise. Yet, due to the erosive effects of the rising sea level, there is a progressive decrease in the natural dune system which brings the seashore line closer to the urban settlements. This means that every year, cyclically, large quantities of sandy material have to be laid down to recreate the natural system [8]. These "green" adaptation processes win time for the protection of coastal cities.

Indeed, if the natural barrier of the shore disappeared, coastal settlements would be exposed to flood impacts. In the adaptation of the territory subject to flooding phenomena, different possible interventions have been and are still being carried out today. Green infrastructure such as beach, forested buffers, bay islands and tidal wetlands absorb the energy of the waves and mitigate coastal flood waters, increasing the resilience of a coastal community while offering valuable ecosystem benefits, such as nurseries and habitat for near shore species. Grey, or traditional, infrastructure such as breakwaters, seawalls and bulkheads need continuous maintenance work to be adapted to the expected extreme weather events, which are increasingly frequent and intense.

Aware that it will not always be possible to make a choice, it is believed that through the ability to read the coastal territory it is possible to intervene and preserve its identity. Moreover, the trend 
of urbanization and urban growth of cities on the coast is expected to continue. Questioning the future of these in-between places on the border between the city and the sea, wondering about the times, cycles and rhythms of this landscape model in the context of climate change is the first step to protect it. Today's scientific methods of observation and decoding of the landscape organize through systematic cataloguing and typological classification the anthropized coastal territory: where cities face the water body. These include the The Coastal Hazard Wheel developed for local, regional and national coastal adaptation planning where the components studied are wave exposure, tidal range, flora and fauna, sediment balance and storms [9].

We achieve that in order to delineate design methodologies for the adaptation and transformation of the coastal landscape we must weave spatial relationships where the essence is cyclical impermanent. Inasmuch as the multiple relationships that are established between the urban space of the coastal agglomeration and the sea are never static but cyclical, as much as tidal times and urban flows. Through the thought exercise we can read between the urban grid and the traces on the beach the continuum made of times and spaces that contribute to give shape to the landscape. Reading the complex relationships and relationships that take place on the space of the margin allows us to understand the continuous transformation that is constantly renewed in the use of space. Through the transformation of space, object of study, and its meaning we can evolve the concept of margin, furthermore then the notion of a limit.

The aim of this short article is to focus the scientific debate on the ever-changing border between the city and the water body: the shore. As the coastal urban agglomeration needs a structured and interdisciplinary urban reading that traces the anthropic and natural characteristics of the landscape, in order to design and adapt the fragile spaces of this "vanishing edge" [10]. Today more than ever a new discourse on the coastal landscape as a common good is needed, not as lovers of the beauty of the pure past [11], but through a critical and operative sense [12]. Reading the lesson of Muratori [12] implies learning that through the typification of the urban fact, the concept of territory changes the role and definition of the landscape. A definition that must be contextualised each time over time, since, as Muratori argued, historical cyclicality has repercussions on the landscape [13]. The territory is, in itself, an organism, the result of the combination of a law of permanence with a law of cyclicality. The Place of experience and memory of humans. Therefore, the reading of the historical process forming the territory and the environment thus understood is fundamental to grasp the field of feasibility of the hypotheses of transformation. The construction of generative landscapes based on cycles, processes and flows that generate different forms of interaction with nature [14].

\section{Conclusion}

In conclusion, recognising the isotropies of these places implies giving them value and integrating them into a targeted environmental design of the urban form. These relationships build a landscape, whose relationship with water we cannot lose because we need "to continue behaving like Narcissus always looking for water surfaces where we can reflect" [15].

\section{References}

1. Church J A, Gregory J M (2001) IPCC 2001: 11 Changes in sea level. Ippc 639-694.

2. Hallegatte S, Ranger N, Mestre O, Dumas P, Corfee-Morlot J, et al. (2011) Assessing climate change impacts, sea level rise and storm surge risk in port cities: A case study on Copenhagen. Climatic Change 104(1): 113-137.

3. Hallegatte S, Green C, Nicholls R J, Corfee-Morlot J (2013) Future flood losses in major coastal cities. Nature Climate Change 3(9): 802-806.

4. IPCC (2018) Summary for Policymakers In Global Warming of $1.5^{\circ} \mathrm{C}$. An IPCC Special Report on the impacts of global warming of $1.5^{\circ} \mathrm{C}$ above pre-industrial levels and related global greenhouse gas emission pathways, in the context of strengthening the global response to the threat of climate change, sustainable development, and efforts to eradicate poverty. In: Masson-Delmotte V, Zhai P, Portner H O; Roberts D, Skea J, et al. (Eds.) World Meteorological Organization, Geneva, Switzerland, p. 32.

5. EC (2014) European Commission. Directive 2014/89/EU Maritime Spatial Planning. European Parliament and of the Council of 23 July 2014.

6. Proenca SB (2018) Reading and interpreting Portuguese Atlantic seashore streets in sea level rise context. ARRC conference Repository $1-8$.

7. Dal Cin F, Fleischmann M, Romice O, Costa JP (2020) Climate Adaptation Plans in the Context of Coastal Settlements: The Case of Portugal. Sustainability 12: 8559.

8. Garcia M (2019) La reinvención de la costa. Diseñando paisajes resilientes. rita11: 106-117.

9. Garcia M (2019) Paisajes generativos. Del control a lo salvaje mediante el diseño resiliente.

10. Hunt JD (2004) The afterlife of gardens. University of Pennsylvania Press, Philadelphia, Pennsylvania, United States Pp. 256.

11. Settis S, (2013) Il paesaggio come bene comune. La scuola di Pitagora.

12. Muratori S (1960) Studi per una operante storia urbana di Venezia. Istituto poligrafico dello Stato, Libreria dello Stato. Roma.

13. Lombardini G (2017) Lambiente come storia: una rilettura dell'ultimo Muratori. Scienze del territorio. Firenze University Press. 5: 227-232.

14. Matos Silva M (2020) Public Spaces for Water. A Design Notebook, CRC Press, ISBN 9780367031008.

15. Morabito V (2012) Paesaggio come pensiero. In: John Dixon Hunt, Sette lezioni sul paesaggio, Libria. 
- Quality Editorial service

- Swift Peer Review

- Reprints availability

- E-prints Service

- Manuscript Podcast for convenient understanding

- Global attainment for your research

- Manuscript accessibility in different formats

( Pdf, E-pub, Full Text, Audio)

- Unceasing customer service

Track the below URL for one-step submission https://juniperpublishers.com/online-submission.php 